\title{
The Usage of Jati Leaves Extract (Tectona grandis L.f) as Color of Lipstick
}

\author{
Setyawaty, R., and Meldina R. Pratama \\ Pharmacy Academy of Kusuma Husada Purwokerto, Indonesia
}

\begin{abstract}
Lipstick is one of the most used cosmetics by women. According to Tranggano and Latifah (2007), lipstick is a cosmetic applied to the lips, to protect the lips in cold and dry air so that the lips are not easy to dry and crack. Lipstick is used by women for a long time so that lipstick should be safe and do not cause irritation. Chemicals substances in the manufacture of lipstick can accidentally be consumed and long-term use so that its accumulation in the body would be harmful to health. Synthetic lipstick color is one part of the dangerous lipstick making material. Synthetic substances can be replaced with natural dyes. The use of natural dye limits on cosmetics is 5-15\% (Mercado, 1991). One example of natural dyes that can be used is the dye from the Jati leaves (Tectona grandis L.f). This study aim is to prove that Jati leaves (Tectona grandis L.f) can be used as a natural dye in the material of lipstick. The method used in this research is the method of extraction maceration with jati leaf samples of 300 grams and ethanol of $96 \%$. Component of lipstick formula which are cera alba, lanolin, vaseline, cetyl alcohol, paraffin solid, oleum ricini, oleum rosae, propylene glycol, butyl hydroxytoluene, methyl paraben, and the addition Jati leaf extract under the concentration of $0 \%, 18 \%$, and $22 \%$. The material of lipstick is easy to apply, stable, brown color, homogeneous, melting point of $60^{\circ} \mathrm{C}$, range $\mathrm{pH}$ between 3 at 4 and lipstick have a breaking point of 500 grams. Jati leaf extract (Tectona grandis L.f) can be used as a dye or color of lipstick.
\end{abstract}

Keywords: chemical substances, component of lipstick, natural dye, Tectona grandis L.f, and lipstick.

\section{INTRODUCTION}

Indonesia is rich in various floras that can be used as a source of natural herbs. One of them is a plant that grows in the area around us is Jati leaves (Tectona grandis L.f.). Jati leaves can be used as natural dyes. Natural dyes are increasingly required its existence. This is because of its safer consideration than synthetic dyes. Utilization of natural dyes in lipstick formulation is trying to avoid the use of harmful synthetic dyes. Natural dye is a dye obtained from plant, animal or mineral sources (Zaidi, 2012).

The young Jati leaves (Tectona grandis L.f) is one of the local resources that contain natural pigments. Jati leaves (Tectona grandis L.f) include plants in the family Verbenaceae that can be used as a natural dye because it contains anthocyanin pigment (Ati et al, 2006). Anthocyanins are pigments that can give blue, purple, violet, magenta, red, and orange in parts of plants such as fruits, vegetables, flowers, leaves, roots, tubers, legumes, and cereals. This pigment is not toxic and safe to consume.

Anthocyanins are found in vacuoles in plant cells. This compound is highly reactive, easily oxidized or reduced, and the glycoside bonds are easily hydrolyzed (Hutching, 1999). In addition to the role of food coloring, anthocyanins are also

\section{Correspondence author:}

Email: rety.setyawaty@gmail.com believed to play a role in biological systems, including the ability of free radical scavenging, cardio protective capacity and the ability to inhibit the initiation stage of chemical reactions that cause carcinogenesis (Ariviani, 2010).

Anthocyanins have polar properties. The anthocyanin must be dissolved in a polar solvent as well. The most effective solvent for dissolving anthocyanins is the acidified methanol with $\mathrm{HCl}$. However, methanol has toxic properties. Therefore, food systems use water or ethanol acidified with $\mathrm{HCl}$ (Delgado et al, 2003). $\mathrm{HCl}$ in ethanol will denature the cell membrane of the plant and then dissolves the anthocyanin pigment out of the cell.

The raw material was readily available because of many Jati plantations are around us. The process of making lipstick uses Jati leaves extract dye through the stages of production. The production stage should be adapted to the way of making good cosmetic (GMP) (Anonymous, 2009). The implementation of GMP is the basic eligibility requirements for implementing quality and safety assurance system that is recognized internationally. Based on the description above, researchers interested in producing lipstick with dyes derived from extracts of Jati leaves (Tectona grandis L.f) using GMP guidelines. The purpose of this study is to prove that Jati leaves can be used as a natural coloring agent in the preparation of lipstick. 
Table I. Formulation lipstick

\begin{tabular}{lccc}
\hline \multicolumn{1}{c}{ Compositions } & I & Formula (\%) & III \\
\cline { 2 - 3 } & I & II & 27.7 \\
Cera alba & 36.2 & 29.3 & 5.8 \\
Vanolin & 7.6 & 6.1 & 24.8 \\
Cetyl alcohol & 32.4 & 26.2 & 4.4 \\
Paraffin solid & 5.7 & 4.6 & 3.2 \\
Oleum ricini & 4.7 & 3.83 & 5.8 \\
Jati leaf extract & 7.6 & 6.1 & 22 \\
Oleum rosae & 0 & 18 & 0.5 \\
Propylen glycol & 0.5 & 0.5 & 5 \\
Butyl hydroxytoluene & 5 & 5 & 0.1 \\
Metil paraben & 0.1 & 0.1 & 0.1 \\
\hline
\end{tabular}

\section{METHODOLOGY \\ Materials}

Jati leaf (Tectonae grandis L.f), $96 \%$ of ethanol, cera alba, lanolin, vaselin, cetyl alcohol, paraffin solid, oleum ricini, oleum rosae, propylene glycol, butyl hydroxytoluene and methyl paraben.

\section{Instruments}

Beaker glass, water bath, thermometer, bunsen, analytical balance, vaporizer cup, glass object, clamp the test tube, suppo mold, mixer rod, lipstick container, measure glass, $\mathrm{pH}$ stick, drop pipette and metal spatula.

\section{Procedure}

Anthoncyanin extractions

First: 300 grams of Jati leaves powder was macerated with $400 \mathrm{~mL}$ of $96 \%$ ethanol in closed place under stirred and protected from light. Keep it for 7 days. Extraction using 96\% ethanol is to obtain anthocyanins. Anthocyanins give the effect of purple, red, blue or brown. Second: the sample from first step is filtered with a cloth several times to obtain a clear filtrate (Voight, 1994). Third: filtrate was concentrated in a water bath.

After obtain a concentrated filtrate containing anthocyanin, next step is preparation of three lipstick formula. The formula namely Formula I without Jati leaves extract $(0 \%)$, Formula II is $18 \%$ of Jati leaves extract, and Formula III is $22 \%$ of Jati leaves extract. This can be said that the composition of Jati leaf extract of Formula I to III, there is an increase of Jati leaf extract content. The composition of cera alba, lanolin, vaseline, cetyl alcohol, paraffin solid, and oleum ricini inversely proportional to the composition of Jati leaf extract. It can be said that the composition of cera alba, lanolin, vaseline, cetyl alcohol, paraffin solid, and oleum ricini is decreasing of Formula I to III. Formulations of lipstick are listed in Table 1.

Manufacturer of lipstick

The first: Nipagin is dissolved in propylene glycol and Jati leaves extract at a concentration of $0 \%, 18 \%$, and $22 \%$ until homogeneous. We were called A. The second: butylhydroxytoluen was dissolved in oleum ricini. We were called B. Mass of $\mathrm{A}$ and $\mathrm{B}$ was mixed. Combination the $\mathrm{A}$ and $\mathrm{B}$ are a mixture 1 . Cera alba, paraffin solid, cetyl alcohol, lanolin and vaseline are weighed and melt. We were called the second mix. The first and second mixtures are then mixed to form a new mixture. The next step is to wait for the mixed temperature equal to the room temperature. After the mixture temperature equals the room temperature then oleum rosae is added and stir until homogeneous. The addition of oleum rosae is intended to give the scent of lipstick. Liquid lipstick is inserted into the mold until solid lipstick is formed. Then put the solid lipstick into the lipstick container.

\section{Evaluation of lipstick}

Breaking point of lipstick

Lipstick suspended load and then do the observation whether the additional burden of how lipstick was broken. The weight of where a broken lipstick breaking point value (Lauffer, 1985).

\section{Melting point of lipstick}

The lipstick melting point is determined by heating the lipstick over the waterbath in the container and a thermometer is placed in it to determine the temperature at which the lipstick melts (Chabib, dkk, 2000). 


\section{pH test of lipstick}

Determination of $\mathrm{pH}$ of lipstick was done by weighing 1 gram sample then melted over water bath, after melting the $\mathrm{pH}$ stick and let it show the pH value of lipstick (Rawlins, 2003).

\section{Homogenous test}

Each lipstick preparation made from Jati leaf extract was examined for homogeneity by applying a certain amount of preparation on a transparent glass. The preparation should show a homogeneous arrangement and no visible coarse grains (Ditjen POM, 1979).

\section{Smear test}

A smear test is done by applying the lipstick on the back of the hand then is observed the number of the colors attached to 5 times (Keithler, 1956).

\section{Stability test}

Stability test of the lipstick is done at each dosage of lipstick. The aim of this test is to determine whether there is a change of forms, color, and smell during storage in room temperature at 1, 5, 10 and then every fifth day until the 30th day (Vishwakarma, 2011).

\section{RESULTS AND DISCUSSION Determination}

The result of plant identification showed that the plant used was Tectona grandis L.f. and familia is Lamiaceae. Indonesian name of Tectona grandis L.f. is Daun Jati.

\section{Anthocyanin extraction}

The purpose of the extraction is to obtain the active substance in the simplicia. The process is the organic solvent will penetrate the cell wall of plants and enter into the cell cavity containing the active substance. The active agent will dissolve in the organic solvent outside the cell then the concentrated solution will diffuse out of the cell and this process will be repeated continuously until there is a balance between the concentration of the liquid inside and the fluid concentration outside the cell. Anthocyanin extraction can be performed with several types of solvents, such as water, ethanol, methanol, but the most effective is to use acidified methanol with $\mathrm{HCl}$. Due to the toxic nature of methanol, usually in food systems used water or ethanol are acidified with $\mathrm{HCl}(\mathrm{MOH}, 1995)$. Anthocyanins give effect to purple, red, blue or brown (Syah, 2005).
Based on the results of this study it was found that the extract using 96\% ethanol produced a brown color. However, the color produced from this study is less obvious because the solvent used to extract the anthocyanin is $96 \%$ ethanol and not acidified with HCl. Ethanol $96 \%$ has alkaline properties. According to Hambali et al (2014), temperature and $\mathrm{pH}$ influence the efficiency of anthocyanin extraction and the diffusion coefficient, the lower the $\mathrm{pH}$ the higher the diffusion coefficient, so the outward color will be more clearly visible (Figure 1).

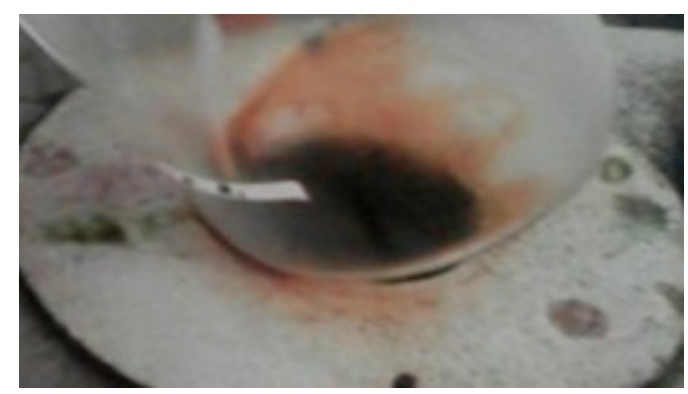

Figure 1. Results from extraction with solvent of $96 \%$ ethanol

\section{Breaking point of lipstick}

Test results showed that the 3 formulation of lipstick $(0 \%, 18 \%$ and $22 \%)$ is easily broken on the addition of a load of 500 grams (Table 1) . Breaking point of lipstick is influenced by the composition of lanolin (Barel, Paye, and Maibach, 2001). Each of lipstick contains lanolin $2.28 \mathrm{~g}$ of $0 \%, 1.84 \mathrm{~g}$ of $18 \%$, and $1.75 \mathrm{~g}$ of $22 \%$. Adeps lanae or also called lanolin. Lanolin is often used in topical preparations and cosmetics. Adeps lanae is used as a carrier of hydrophobic substances and is a substance that is practically insoluble in water (Rowe et al., 2009). Adeps lanae is usually used as a moisturizer, increases the strength of the lipstick, and prevents the tendency of the oil to separate (Jellinek, 1970).

\section{Melting point of lipstick}

Test results of melting point (MP) (Table II). Table II shows that the lipstick melts at a temperature of $60^{\circ} \mathrm{C}$. Test results lipstick melting point, of the three formulas $(0 \%, 18 \%$ and $22 \%)$ had a mean melt at a temperature of $60^{\circ} \mathrm{C}$. This preparation included in the preparation of a good lipstick lipstick that good preparation is the preparation of lipstick with a melting point above $50{ }^{\circ} \mathrm{C}$ (Vishwakarma, 2011). It means the lipstick has good physical characteristics. 
Table I. Breaking point of lipstick

\begin{tabular}{cccc}
\hline Formula & Treatment (replication) & Load (gr) & Average (gr) \\
\hline I (0\%) & 1 & 500 & 500 \\
II $(18 \%)$ & 2 & 500 & 500 \\
& 1 & 500 & \\
III $(22 \%)$ & 2 & 500 & 500 \\
& 1 & 500 & \\
\hline
\end{tabular}

Table II. Melting point (MP)

\begin{tabular}{cccc}
\hline Formula & Treatment (replication) & Melting point $\left({ }^{\circ} \mathbf{C}\right)$ & Average $\left({ }^{\circ} \mathbf{C}\right)$ \\
\hline I $(0 \%)$ & 1 & 60 & 60 \\
II $(18 \%)$ & 2 & 60 & 60 \\
& 1 & 60 & 60 \\
III $(22 \%)$ & 2 & 60 & 60 \\
\hline
\end{tabular}

Table III. pH of lipstick test

\begin{tabular}{cccc}
\hline Formula & Treatment (replication) & pH & Average pH \\
\hline I $(0 \%)$ & 1 & 3 & 3 \\
II $(18 \%)$ & 2 & 3 & 4 \\
& 1 & 4 & \\
III $(22 \%)$ & 2 & 4 & 4 \\
& 1 & 4 & \\
\hline
\end{tabular}

Table IV. Homogeny

\begin{tabular}{ccc}
\hline Formula & Treatment (replication) & Texture \\
\hline I $(0 \%)$ & 1 & Homogeneous \\
II $(18 \%)$ & 2 & Homogeneous \\
& 1 & Homogeneous \\
III $(22 \%)$ & 2 & Homogeneous \\
& 1 & Homogeneous \\
\hline
\end{tabular}

\section{pH test of lipstick}

Results $\mathrm{pH}$ of lipstick using colour of Jati leaf extract (Tectona grandis L.f) under a concentration of $18 \%$ and $22 \%$ has a $\mathrm{pH}$ value of 4, which correspond to physiological $\mathrm{pH}$ skin of the lips is \pm 4 (Lauffer, 1985). The purpose of the $\mathrm{pH}$ made in accordance with Lauffer (1985) is to avoid irritation of the lips. The $\mathrm{pH}$ test performed gives results as in Table III, where all the lipstick has a $\mathrm{pH}$ of 4 . This means that the $\mathrm{pH}$ of the lipstick is made, present in skin of lip conditions.

\section{Homogeneity test}

Formula II and III (18\% and $22 \%$ ) of the test results have a homogeneous physical condition. In the process of making the most important lipstick is the process of grinding to produce a homogeneous color, in the process of color mixing must also be considered (Table IV).

Homogeneity test results showed that all lipstick preparations did not show presence coarse grains when the lipstick is applied to transparent glass. This indicates that the lipstick made has a homogeneous arrangement (Ditjen POM, 1979).

\section{Smear test}

Based on the smear test, topical preparations $0 \%$ is visible white color. $18 \%$ and $22 \%$ give a brown color in 5 times smear 
Setyawaty, $R$

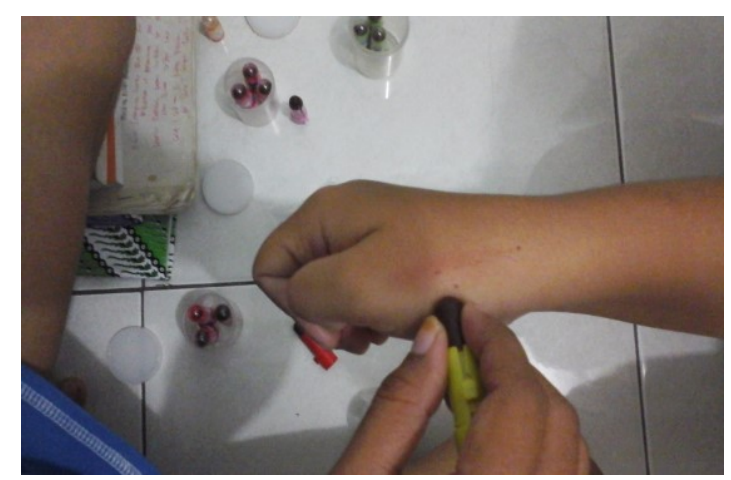

Figure 2. Smear test

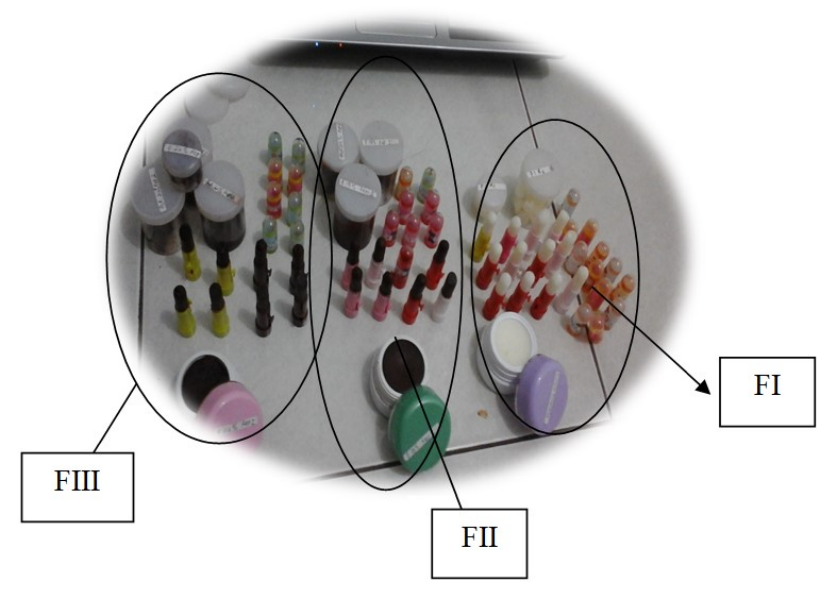

Figure 3. Lipstick using Jati leaves extract

Table V. Stability of lipstick using Jati leaves extract (Tectona grandis L.f)

\begin{tabular}{|c|c|c|c|c|c|c|c|c|}
\hline \multirow{2}{*}{ Observation } & \multirow{2}{*}{ Formula } & \multirow{2}{*}{$\begin{array}{c}\text { Treatment } \\
\text { (replication) }\end{array}$} & \multicolumn{6}{|c|}{ Observation times (day) } \\
\hline & & & 15 & 10 & 15 & 20 & 25 & 530 \\
\hline \multirow[t]{6}{*}{ Color } & $0 \%$ & 1 & W W & $\mathrm{W}$ & $\mathrm{W}$ & $\mathrm{W}$ & $\mathrm{W}$ & $\mathrm{W}$ \\
\hline & & 2 & W W & $\mathrm{W}$ & $\mathrm{W}$ & $\mathrm{W}$ & W & $\mathrm{W}$ \\
\hline & $18 \%$ & 1 & B B & $3 \mathrm{~B}$ & B & B & $\mathrm{B}$ & $\mathrm{B}$ \\
\hline & & 2 & $\mathrm{~B} \mathrm{~B}$ & $\mathrm{~B}$ & $\mathrm{~B}$ & $\mathrm{~B}$ & $\mathrm{~B}$ & $\mathrm{~B}$ \\
\hline & $22 \%$ & 1 & $\mathrm{~B} B$ & $\mathrm{~B}$ & $\mathrm{~B}$ & $\mathrm{~B}$ & $\mathrm{~B}$ & $\mathrm{~B}$ \\
\hline & & 2 & B B & B & B & B & $\mathrm{B}$ & B \\
\hline \multirow[t]{6}{*}{ Smell } & $0 \%$ & 1 & SS SS & S SS & SS & SS & SS & SS \\
\hline & & 2 & SS SS & S SS & SS & SS & SS & SS \\
\hline & $18 \%$ & 1 & SS SS & $S$ SS & SS & SS & SS & SS \\
\hline & & 2 & SS SS & S SS & SS & SS & SS & SS \\
\hline & $22 \%$ & 1 & SS SS & S SS & SS & SS & SS & SS \\
\hline & & 2 & SS SS & S SS & SS & SS & SS & SS \\
\hline \multirow[t]{6}{*}{ Shape } & $0 \%$ & 1 & $\mathrm{G} \quad \mathrm{G}$ & $G \quad G$ & $\mathrm{G}$ & G & $\mathrm{G}$ & $G$ \\
\hline & & 2 & $\mathrm{G} \quad \mathrm{G}$ & $\mathrm{G}$ & $\mathrm{G}$ & $\mathrm{G}$ & $\mathrm{G}$ & $\mathrm{G}$ \\
\hline & $18 \%$ & 1 & $\mathrm{G} \quad \mathrm{G}$ & $\mathrm{G}$ & $\mathrm{G}$ & $\mathrm{G}$ & $\mathrm{G}$ & G \\
\hline & & 2 & G G & $\mathrm{G}$ & $\mathrm{G}$ & $\mathrm{G}$ & $\mathrm{G}$ & G \\
\hline & $22 \%$ & 1 & $\mathrm{G} \quad \mathrm{G}$ & $\mathrm{G}$ & $\mathrm{G}$ & $\mathrm{G}$ & $\mathrm{G}$ & G \\
\hline & & 2 & $\mathrm{G} \quad \mathrm{G}$ & $\mathrm{G}$ & G & $\mathrm{G}$ & $\mathrm{G}$ & G \\
\hline
\end{tabular}

Annotation: B : Good; SS: Specific smell; B : Brown; W : White 
(Figure 2). The test results topical preparations lipstick on a formula of $18 \%$ and $22 \%$ had a brown color when 5 times basting.

Lipstick preparations are said to have a good smear if the lipstick provides intensive, even and homogeneous color when applied on the skin of the back of the hand.

\section{Stability test}

The observation of stability of lipstick is lipstick are storage at room temperature storage for 30 days no change in color, smell, and shapes. Lipstick under a concentration of $18 \%$ and $22 \%$ of Jati leaves extract, likely to be stable after being stored for 30 days. Base composition of lipstick causes lipstick to be stable because the base is a major factor in making lipstick (Wirawan, 2016) (Table V).

One compound found in the leaves of young Jati is anthocyanin. Anthocyanins produce red to purple, but in the manufacture of lipstick using ethanol extract of leaves of teak (Tectona grandis L.f) produce a brown color because Jati leaves also contained tannin that produce a brown color. The red color on the leaves of young teak does not appear in the manufacture of lipstick due to anthocyanin compounds most stable at $\mathrm{pH} 3$ (Erinda, 2011). pH value resulting in the manufacture of this lipstick is 4 which is appropriate as it nears the lip skin physiological $\mathrm{pH}$ (Lauffer, 1985). The important thing in anthocyanin is its stability, because stability of anthocyanin is influenced by environmental conditions, ie by several factors such as $\mathrm{pH}$ and oxygen (Latifah, 2011). In this study the stability of anthocyanin is influenced by the $\mathrm{pH}$ of anthocyanin, wherein the anthocyanin most stable at $\mathrm{pH} 3$ and $\mathrm{pH}$ influenced also by oxygen, ie, when dissolved in a solution mixture, anthocyanin will oxidize slowly, so that the color red should appear, it is oxidized. Therefore, brown color appears in the lipstick.

\section{CONCLUSION}

Jati leaves extract (Tectonae folium) teak leaf extract can be made lipstick preparations under concentrations of $18 \%$ and $22 \%$. Lipstick will break if given a load of 500 grams and melt of $60^{\circ} \mathrm{C}$. Lipstick has homogeneous characteristics and no change of color, odor and shape when the lipstick kept until 30 days. $\mathrm{pH}$ of the lipstick is made, present in lip $\mathrm{pH}$ conditions is \pm 4 . Lipstick on a formula of $18 \%$ and $22 \%$ had a brown color when 5 times basting.

\section{REFERENCES}

Anonymous. 2009. Kaidah Cara Pembuatan Obat yang Baik (CPKB). BPOM RI: Semarang.

Ariviani S. 2010. Total Antosianin Ekstrak Buah Salam dan Korelasinya dengan Kapasitas Anti Peroksidasi pada Sistem Linoelat. Jurnal Agrointek. Vol 4. No 2. Hal : 121-127.

Ati, Neltji Herlina, dkk. 2006. Komposisi dan Kandungan Pigmen Tumbuhan Pewarna Alami Tenun Ikat di Kabupaten Timor Tengah Selatan, Propinsi Nusa Tenggara Timur. Indo. J. Chem. 6(3): 325 - 331.

Barel, A.O., Paye, M., and Maibach, H.I. 2001. Handbook of Cosmetic Science and Technology. Informa Health Care. USA. pp 392, 409-410,670-671, 773.

Chabib, Lutfi, Muhammad Ikhwan rizki, dan Farida Hayati. 2000. Formulasi Nanopartikel Karotenoid Ekstrak Wortel (Daucus Carrota L.) Sebagai Pewarna Lipstik, pp 809-822.

Delgado-Vargas F., Paredes-López O. 2003. Anthocyanins and betalains. In "Natural Colorants for Food and Nutraceutical Uses". CRC Press, Boca Raton, pp: 167-219.

Ditjen POM. 1979. Farmakope Indonesia. $3^{\text {rd }}$ edition. Jakarta. pp 33, 459, 633.

Erinda. 2011. Ekstraksi Pewarna Alami Dari Daun Jati Dan Analisa Tekno-Ekonomi Skala Laboratorium. Jurnal Industria. Vol.3 No 1 (P) 62-72.

Hambali, M., Mayasari, F., and Noermansyah F. 2014. Esktraksi Antosianin dari Ubi Jalar engan Variasi Konsentrasi Solven dan Lama Waktu Ekstraksi. Jurnal Teknik Kimia, Universitas Sriwijaya, 20(2): 25-35.

Hutching. 1999. Food Color and Appearance. $2^{\text {nd }}$ ed. Gaithersburg, Md.: Aspen Publishers, Inc.

Jellinek. 1970. Formulation and Function of Cosmetics, John Willey and Sons, Inc., USA, pp 113-114, 121, 431.

Keithler. W. 1956. Formulaion of Cosmetics and Cosmetic Industry. pp 153-155.

Latifah. 2011. Optimasi Proses Pembuatan Lipstik Dengan Penambahan Berbagai Konsentrasi Malam Lebah. Jurnal Program Studi Hasil Ternak. IPB. Vol.3 (4): 67-79.

Lauffer. 1985. Kosmetik dan Pewarna pada Bibir. Jurnal Biologi Universitas Jendral Sudirman. Vol.2 (3) : 65-80.

Mercado, C. G., dkk. 1991. Lipstick Formulation and Method, United States Patent, No. 4996.044, pp 3.

Ministry of Health (MOH). 1995. Materia Medika Indonesia, Jakarta. Vol. VI. 
Rawlins, E.A. 2003. Bentley's Textbook of Pharmaceutics. $18^{\text {th }}$ Edition, London, Bailierre Tindall, pp 355.

Rowe, R.C., Sheskey, P.J., and Quinn, M. E. 2009. Handbook of Pharmaceutical Exipients $6^{\text {th }}$ $E d$, Pharmaceutical Press and American Pharmacists Association, United Kingdom, pp 1, 283, 378-380, 549-550, 741-742, 779.

Syah, D. 2005. Manfaat dan Bahaya Bahan Tambahan Pangan. Skripsi. IPB. Bogor.

Tranggono, I.R., and Latifah, F. 2007. Buku Pegangan Ilmu Pengetahuan Kosmetik, Gramedia Pustaka Utama, Jakarta, pp 93, $100,101,108,152$.
Vishwakarma. 2011. Formulation and Evaluation Lipstick. International Journal of Drug Discovery Herbal Research. 1 (1): 18-19.

Voight. 1994. Buku Pelajaran Teknologi Farmasi. Gajah Mada University Press : Yogyakarta. 566-576.

Wirawan, Pho, V. 2016. Pengaruh Komposisi Lanolin dan Beeswax sebagai Basis Lipstik terhadap Sifat fisik dan Stabilitas Lipstik dengan Pewarna dari Ekstrak Kulit Manggis (Garcinia mangostana L.). Skripsi Sarjana Program Studi Farmasi. Yogyakarta.

Zaidi. 2012. Formulasi Lipstick Menggunakan Ekstrak Biji Coklat Sebagai Pewarna. Jurnal of Pharmaceutics and Pharmacology. Vol.1 (1) : 78-86. 